\title{
Vegetation structure and Carbon Stock of Two Community Managed Shorea robusta Forests of Dhangadhi, Nepal
}

\author{
Gyanu Joshi', Krishna Prasad Sharma ${ }^{2 *}$, Mukesh Kumar Chettri ${ }^{1}$ \\ ${ }^{1}$ Department of Botany, Amrit Campus, Tribhuvan University, Kathmandu, Nepal \\ ${ }^{2}$ Department of Botany, Trichandra Campus, Tribhuvan University, Kathmandu, Nepal \\ *E-mail: botanist.krishna@gmail.com
}

(Received:14 January. 2021, Received in revised form: 20 April, Accepted: 4 May 2021, Available Online)

\section{Highlights}

- Two community forests with different soil moisture regimes were studied.

- Total plant species richness was high at wet forest but herbs diversity was high at dry forest.

- The wet forest facilitated the diversity of tree and shrub species, but dry forest favoured herb diversity and seedlings because of the open canopy.

- The carbon stock of wet MCF was higher than the dry SCF.

- Construction of ponds in dry Sal forests is recommended to increase forest carbon stock, to be benefited from Carbon trade under REDD+.

\begin{abstract}
Community forests play a vital role in sustainable development and storing carbon stock to mitigate global warming. This study aimed to assess the plant diversity, carbon stock and regeneration status of two Shorea robusta forests managed by the community - Manehara Community Forest (MCF) and Siddhanath community forests (SCF) of Kailali district, Nepal. These two forests differ in the moisture regime-MCF is with ponds and streams and is mostly wet, but SCF is primarily dry with no ponds and streams. To examine vegetation status and carbon stock in these two forests, twenty circular plots of $20 \mathrm{~m}$ radius was laid in each forest using stratified random sampling. Within each main plot, two subplots of $5 \mathrm{~m}$ radius and three subplots of $2 \mathrm{~m}$ radius were laid to study shrub and herb characteristics, respectively. Soil sampling was also done to analyze the role of soil moisture in carbon stock and regeneration. For this, soil samples of each plot was collected up to $20 \mathrm{~cm}$ depth. Altogether 100 plant species were recorded from the study forests. Tree and shrub diversity was higher in MCF than in SCF, but herb diversity and seedling numbers were higher in relatively dry SCF than in MCF. The carbon stock of MCF (92.99t/ha) was higher than in SCF $(51.94 \mathrm{t} / \mathrm{ha})$. In both forests, carbon stock increased with the increasing basal area $(P=0.0001)$. A significant strong positive relationship $(P=0.0001)$ between density and carbon stock was found in SCF, but this relation was weak $(P=0.018)$ in $M C F$. Both community forests were fairly regenerating with a good number of small aged individuals, SCF shows an inverted J shaped density diameter (d-d) curve, whereas MCF shows a bell-shaped d-d curve.
\end{abstract}

Keywords: species richness, regeneration, bulk density, soil moisture

\section{Introduction}

Carbon stock is the total quantity of carbon contained in a reservoir which can accumulate or release carbon [1]. Compared to croplands, forests sequester 20-100 times more carbon per unit area which play a profound role in reducing carbon dioxide

${ }^{*}$ Corresponding author 
levels [2]. The $\mathrm{C}$ sequestration is much faster in a young and regenerating forest, but $\mathrm{C}$-stock is more in an old and mature forest $[3,4]$. The world's forests contain up to $80 \%$ of all above ground $\mathrm{C}$ and nearly $40 \%$ of all below ground (soil, litter and roots) terrestrial carbon [5].

Nepal started the community forestry program in the late 1970s, and by 2018 total of 2237670.5 ha of forest area has been handed over to 22,266 community forest users group [6]. Community forest has been claimed to act as a source of $\mathrm{C}$ sink, storing about $20 \%$ of the total carbon stock [7] in Nepal. Forest carbon sequestration and dynamics is an emerging issue, particularly for developing countries like Nepal [7]. Nepal forest contributes approximately $176.95 \mathrm{t} / \mathrm{ha}$ carbon stock where tree component contributes $61.53 \%$, forest soil contributes $37.80 \%$, and litter and debris contributes $0.67 \%$ [8]. Carbon stock did not vary significantly with species richness and litter cover, but is usually increased with the management duration [9].

The regeneration and productivity of forest are determined by analyzing the current ratio of different age group [10]. For particular ecosystem various natural and anthropogenic activities such as drought, forest fire, disease outbreak, deforestation, overexploitation of resources, grazing, fragmentation and industrialization affect the forest diversity and regeneration [11, 12]. Similar to other factors soil characteristics also affect the biodiversity and regeneration of a forest. Generally, soil with low bulk density facilitates root growth along with optimum movement of air and water through the ground, whereas soil with a bulk density of more than $1.6 \mathrm{~g} / \mathrm{cm}^{3}$ tend to restrict root growth $[13,14]$.

Anthropogenic carbon emission by developed countries is a major challenge of the $21^{\text {st }}$ century. The severe effects of anthropogenic carbon emission are global warming and biodiversity loss [11]. The parties of UNFCCC have approved the $\mathrm{REDD}^{+}$scheme to provide benefits for the community forests of the developing countries [9]. To get such help from the carbon trade, forest carbon stock should be appropriately recorded. To generate the baseline data, this research was proposed in the funding support of the Ministry of Industry, Tourism, Forests and Environment of Sudurpaschim province, Nepal. The information obtained from this research support planning and implementation for forest management and conservation.

\section{Materials and Methods}

\section{Study area}

This study was carried out in two community forests of Dhangadhi, Kailali district, Nepal. Siddhanath community forest (SCF) is located between $28^{\circ} 40^{\prime} 30^{\prime \prime}$ to $28^{\circ} 40^{\prime} 54^{\prime \prime} \mathrm{N}$ and $80^{\circ} 38^{\prime} 13$ to $80^{\circ} 39^{\prime} 7^{\prime \prime} \mathrm{E}$ and Manehara community forest (MCF) is located between $28^{\circ} 41^{\prime} 1$ 'to $28^{\circ} 41^{\prime} 57^{\prime \prime} \mathrm{N}$ and $80^{\circ} 37^{\prime} 38^{\prime \prime}$ to $80^{\circ} 38^{\prime} 43$ ' $\mathrm{E}$ with the altitude ranging from 123 to $191 \mathrm{~m}$ asl (Figure 1). The climate of the study area is tropical. The temperature recorded at the nearest weather station (Attariya meteorological station) from 1993 to 2019 showed an average annual temperature of $24.6^{\circ} \mathrm{C}$ and average annual rainfall of 1713 $\mathrm{mm}$ of the study area.

The study area was dominated by Shorea robusta, and the other associated species were Terminalia chebula, Terminalia tomentosa, Syzygium cumini, Haldina cordifolia and Schleichera oleosa. The two

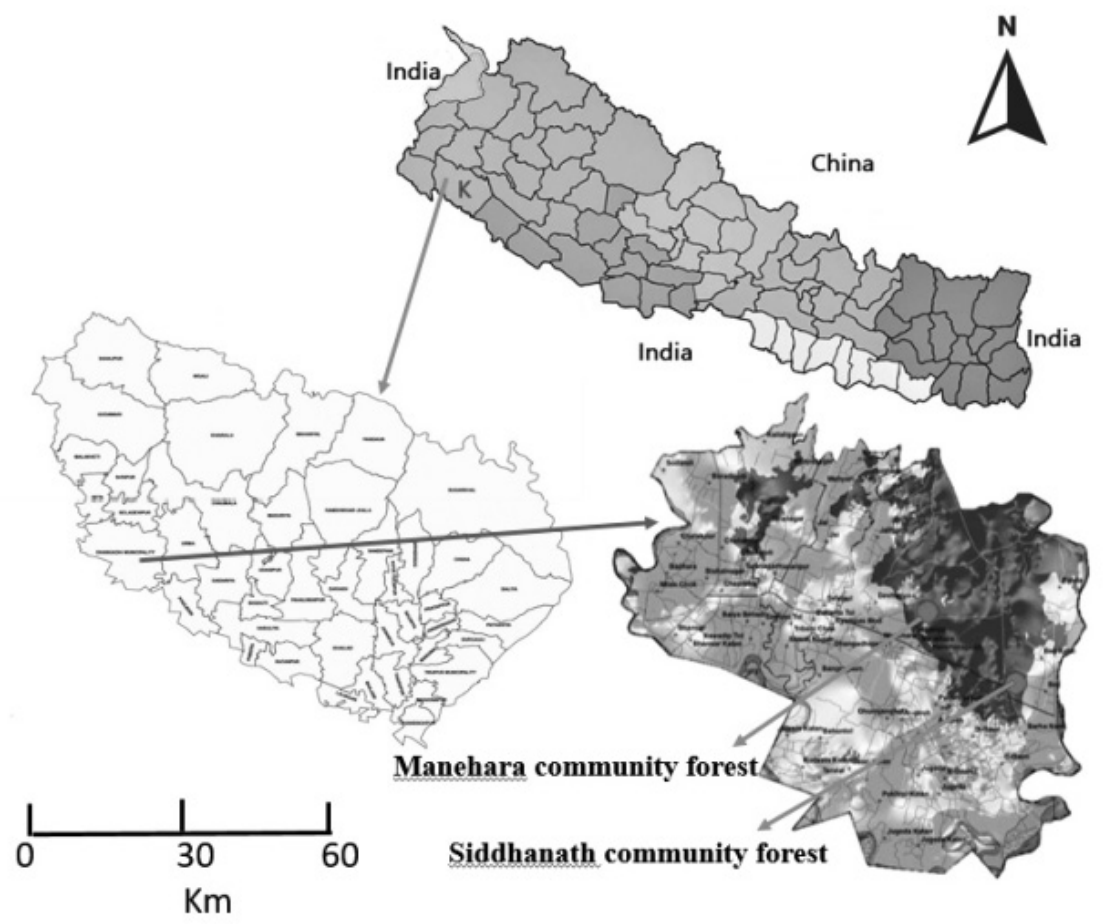

Fig 1. Map of the study area; Map of Nepal with provinces and districts (a), Kailali district with local administrative units (b), Location of the community forests (MCF and $S C F)$ in Dhangadhi sub-metropolitan city (c). 
study forests are different in moisture conditions. In Manehara community forest, there are some small ponds and streams, but Siddhanath community forest was comparatively dry with no ponds and streams. Manehara community forest is divided into three blocks and Siddhanath community forest into five blocks to prevent forest fire. Siddhanath community forest was handed over to the user groups (1057 users) in $2000 \mathrm{AD}$ and covers 167.25 hectares whereas Manehara community forest was handed over in $2007 \mathrm{AD}$ for 893 users and covers 285.05 hectares.

\section{Field Sampling}

Stratified random sampling was used for vegetation sampling in April-May, 2019. Twenty circular plots of 20m radii were laid for each forest. For each sample plot, vegetation and field characteristics were recorded. The geographical locations of each plot were recorded by using the Global Positioning System (GPS). Canopy cover (\%) was estimated visually from the centre of each plot. The diameter of trees more than $10 \mathrm{~cm}$ at breast height (DBH $>1.37 \mathrm{~m}$ ) were measured using diameter tape [15]. In each main plot, two subplots of $5 \mathrm{~m}$ radii was laid to record shrub characteristics, and three subplots of $2 \mathrm{~m}$ radii were laid to record herb and seedling characteristics. To analyze the regeneration status of forest, the number of sapling and seedling of trees were counted in plots of $5 \mathrm{~m}$ and $2 \mathrm{~m}$ radii, respectively. For this, individuals with height between $15 \mathrm{~cm}$ and $1.37 \mathrm{~m}$ were considered as sapling, and with height less than $15 \mathrm{~cm}$ were considered as seedlings [9]. The basal area of trees was calculated to show its relationship with regeneration [15]. From each plot, 5 soil samples were collected using soil corer of $20 \mathrm{~cm}$ long and $3.4 \mathrm{~cm}$ internal diameter. Soil samples from each plot were homogenized and a representative sample was prepared. The physicochemical parameters such as bulk density, soil moisture and soil organic carbon were measured and compared.

\section{Estimation of Biomass and Carbon Stock}

The allometric equation was used to estimate the biomass and carbon stock [16]. Wood densities were taken from wood density index [17].

\section{Data analysis}

All statistical tests were performed using excel 2016 and SPSS 16.0. The data was normalized for parametric tests. Correlation and regression analysis was done to show the relationship of carbon stock with other variables like basal area, density, soil carbon, soil moisture and bulk density. Similarly, a total number of plants of all species recorded in all the plots were divided into different size classes based on DBH of $15 \mathrm{~cm}$ intervals. The density-diameter (d-d) curve of plants was prepared to analyze the distribution pattern of individuals in DBH classes.

\section{Results and Discussion}

\section{Properties of forest stand}

Altogether 100 plant species were recorded from the study forests. Total plant species richness was higher in MCF (53) than in SCF (47). Tree species were higher in MCF (21) than in SCF (13), but herb species was higher in SCF (19) than in MCF (13) (Figure 2); that might be due to the dryness and low density of shrubs in SCF [18]. High herb diversity in the areas with less shrub cover might be due to the response of herbs to the removal of shrubs or the low availability of shrubs. Possibly MCF with high moisture content must have supported more species of shrubs and trees.

Regeneration is the determinant factor for the sustainability of forest. Regeneration status of the forest is said to be good if forests have seedling $>5000$ and sapling $>2000$ per hectare [19]. In this study number of seedling and sapling in the Siddhanath community forest is 169,000 and 13,090 per hectare, respectively, and the seedling and sapling number in Manehara community forest are 68,250 and 5,520 per hectare, respectively. This indicates good regeneration, as suggested by some similar research [19].

In Siddhanath community forest, stem density increased with decreasing diameter of stem, except in diameter class 55-70 $\mathrm{cm}$. Thus the density-diameter curve appeared almost inverted J-shaped (Figure 5). Some other research also suggests that a relatively open canopy favours forest regeneration [20]. In Manehara community forest, stem density increased with increasing diameter up to a certain limit $(40-55 \mathrm{~cm})$; beyond this, stem density decreased with further increasing diameter; thus the d-d curve appeared as a bell-shaped (Figure 5), which has been suggested as the mature forest [21].

Among this two community forest, the relatively dry Siddhanath community forest had better tree regeneration than the Manehara community forest. This might be due to the open canopy and more plant with the less basal area than in the Manehara community forest (Table 1 and Figure 3). Some research finding also suggests that open canopy favours the regeneration of lightdemanding species [22]. In Shorea robusta forest presence of canopy gaps allowed sufficient light to reach the forest floor and made the environment dry, which is a favorable condition for the growth and development of its seedling and sapling. Thus light 
is considered a very critical abiotic factor, which played two roles for increasing photosynthesis and ground temperature, and in turn also accelerated litter decomposition [22].

Basal area cover of woody plant species is an important vegetation character to access the standing biomass and productivity [9]. In average, the total basal area of all woody species of Manehara community forest is higher $\left(26.26 \mathrm{~m}^{2} / \mathrm{ha} \mathrm{vs} 15.06 \mathrm{~m} / \mathrm{ha}\right)^{2}$ but density of trees was higher in dry Siddhanath community forest (Table 1).

Soil characteristics of the forest were also analyzed to relate the role of soil factors in the diversity and regeneration of the forest. The mean value of soil carbon, soil moisture and canopy cover was higher in Manehara community forest, but bulk density shows the reverse result (Table 1). In Manehara community forest, high plant diversity is correlated with low bulk density. Low bulk density or low compactness of soil might have facilitated for optimum movement of air and water through the soil particles and this probably favored seed germination of different species [13].

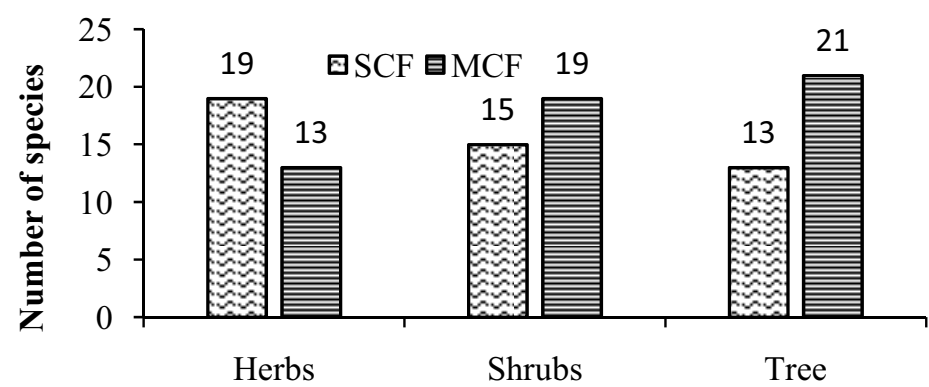

Habit

Fig 2. Species richness in Siddhanath community forest (SCF) and Manehara community forest (MCF).

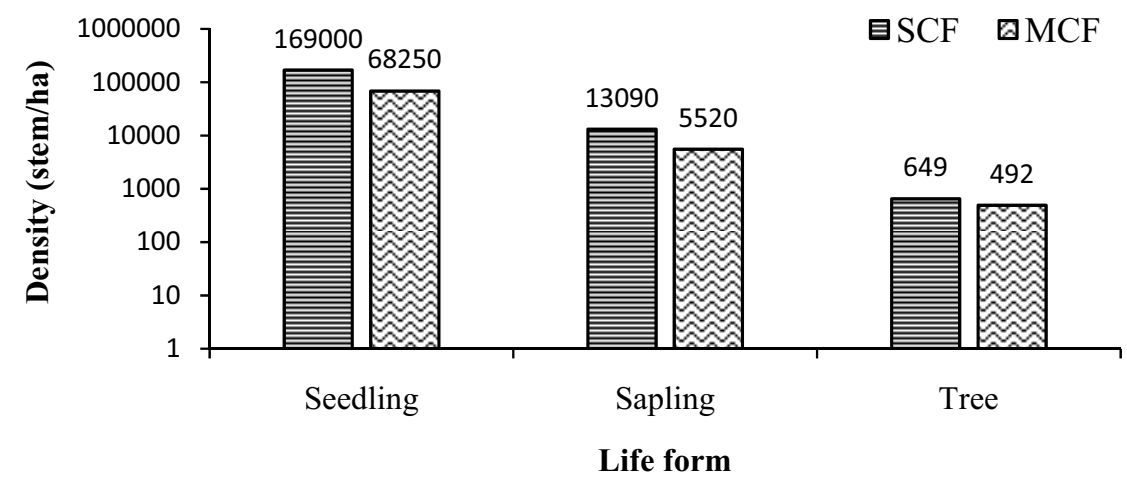

Fig 3. Life forms to show the regeneration status of all species in Siddhanath community forest (SCF) and Manehara community forest (MCF).

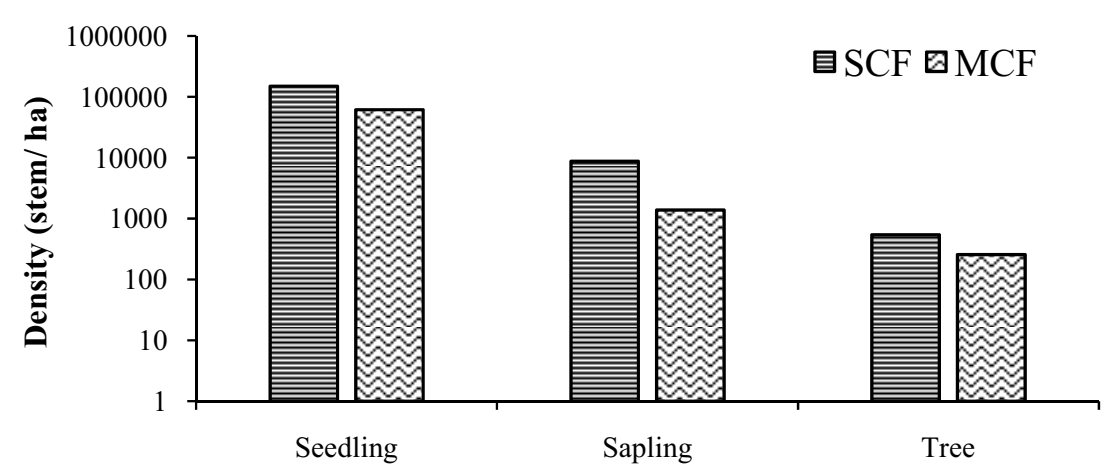

Life form

Fig 4. Life form diagram to show the regeneration status of Shorea robusta species in both Siddhanath community forest (SCF) and Manehara community forest (MCF). 


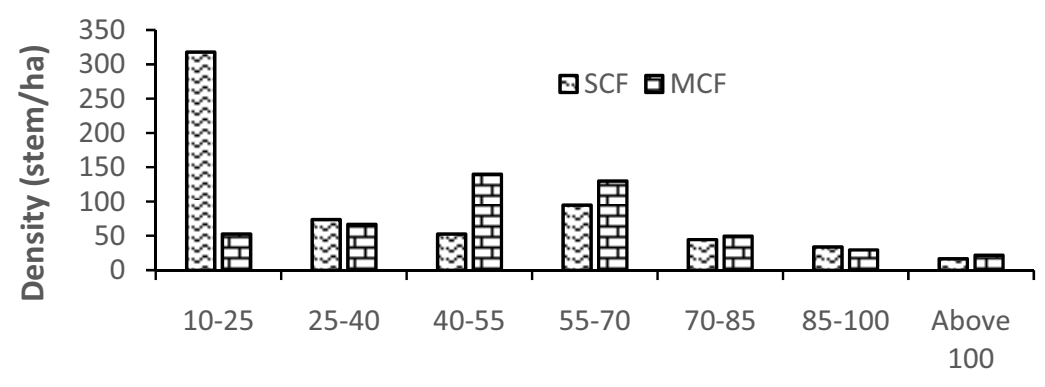

DBH class $(\mathrm{cm})$

Fig 5. Density diameter relationship of trees $\geq 10 \mathrm{~cm}$ in Siddhanath community forest (SCF) and Manehara community forest (MCF).

Table 1. Mean value of the basal area, density of tree, soil organic carbon, soil moisture, bulk density, and canopy cover in two community forest.

\begin{tabular}{|l|c|c|}
\hline Variables & Siddhanath community forest & Manehara community forest \\
\hline Basal area $\left(\mathrm{m}^{2} / \mathrm{ha}\right)$ & 15.06 & 26.26 \\
\hline Density of tree $(\mathrm{stem} / \mathrm{ha})$ & 32.45 & 24.6 \\
\hline Soil carbon $(\%)$ & 2.475 & 3.003 \\
\hline Soil bulk density $(\mathrm{g} / \mathrm{cm} 3)$ & 1.43 & 1.34 \\
\hline Soil moisture $(\%)$ & 1.97 & 16.31 \\
\hline Canopy cover $(\%)$ & 27.1 & 34 \\
\hline
\end{tabular}

\section{Tree carbon stock}

The total carbon stock of trees was recorded more in Manehara community forest (Table 2). In both forests, the above-ground biomass holds more carbon than in below-ground biomass for trees. However, the regeneration is perfect; both forests shows relatively low carbon stock compared to similar other forests; it might be due to the dominance of small-sized trees [3, 4]. Most of the researches suggest that productivity and carbon content is positively correlated with plant diversity [23, 24]. Our study also shows that Manehara community forest with plant biodiversity has higher carbon stock (Figure.1). However, some research [23] reported a positive but very weak correlation between carbon stock and species richness in the collaborative forests. Similar study conducted in the Netherlands also supported that the variation of carbon stock does not depend upon species diversification, and shows a positive but weak correlation between carbon stock and biodiversity [24].

Basal area of tree species was found higher in Manehara community forest, and the relationship of basal area with total $\mathrm{C}$-stock was found to be significant $(\mathrm{P}=0.0001)$. However, the density of tree species was higher in Siddhanath Community forest where the relationship with total C-stock was insignificant (Table 3), which support the results of some Hill sal forests of Dhading district, Nepal [9]. Some research also shows that the rate of carbon sequestration is much higher in young individuals, but $\mathrm{C}$-stock is relatively high in an old-aged forests $[3,4,25]$. Our result also supports the above-mentioned statements, here standing C-stock of the old-aged Manehara community forest was much higher than the young plant dominated Siddhanath community forest.

Table 2. Above and below ground carbon stock (t/ha) in two community forests based on soil moisture.

\begin{tabular}{|c|c|c|c|}
\hline Name of forest & Above ground carbon stock & Below ground carbon stock & Total carbon stock \\
\hline SCF & 43.462 & 8.5336 & 51.94 \\
\hline MCF & 77.4167 & 15.3695 & 92.99 \\
\hline
\end{tabular}

Carbon stock relationship with soil moisture and soil organic carbon (0-20 cm depth) was negative and insignificant for both forests (Table 3), but some other studies have shown significant positive correlation between soil organic carbon and soil moisture for $0-10 \mathrm{~cm}$ depth $[26,27]$. This indicates the soil moisture played an important role in soil carbon sequestration at upper most surface of forest ecosystem. At the community level, high soil moisture 
contributes to the high net primary productivity and ultimately high soil organic carbon accumulation. However, some research suggests the increasing C-stock is correlated with increased total soil organic carbon [9].

The correlation of carbon stock in both forests was positive but insignificant with bulk density. At the community level, the bulk density of the Siddhanath community forest was higher, which indicates the Manehara community forest has less soil compaction and high porosity in soil suitable for root growth. In general, soil bulk density greater than $1.6 \mathrm{~g} / \mathrm{cm}^{3}$ is tend to restrict the growth of plants [14]. Our study shows that there was an insignificant effect of bulk density and soil carbon with total carbon.

Table 3. Relationship between carbon stock and soil parameters

\begin{tabular}{|l|l|l|l|l|}
\hline Correlation & $\begin{array}{l}\text { Siddhanath } \\
\text { community forest }\end{array}$ & $\begin{array}{l}\text { Manehara } \\
\text { community forest }\end{array}$ & $\begin{array}{l}\text { P-value in } \\
\text { Siddhanath } \\
\text { community forest }\end{array}$ & $\begin{array}{l}\text { P-value in } \\
\text { community } \\
\text { forest }\end{array}$ \\
\hline Carbon stock and soil moisture & -0.022 & -0.209 & 0.926 & 0.377 \\
\hline Carbon stock and bulk density & 0.142 & 0.350 & 0.551 & 0.131 \\
\hline $\begin{array}{l}\text { Carbon stock and soil organic } \\
\text { carbon }\end{array}$ & -0.027 & -0.136 & 0.914 & 0.568 \\
Carbon stock and basal area & 0.993 & 0.893 & 0.0001 & 0.0001 \\
Carbon stock and density & 0.954 & 0.254 & 0.0001 & 0.018 \\
\hline
\end{tabular}

\section{Conclusions}

The biodiversity and carbon stock was much higher in the Manehara community forest due to optimum moisture throughout the year. The forest regeneration is relatively better in the Siddhanath community forest due to the open canopy, and the resurgence in the Manehara community forest was also good. The correlation of soil organic carbon and carbon stock is negative, but the carbon stock of trees increased with increasing soil organic carbon and soil moisture. Hence, for better carbon stock, moisture might have played a crucial role in the Manehara community forest. With these conclusions, we strongly recommend making ponds in some high land areas to improve the biodiversity, forest regeneration and carbon stock.

\section{Acknowledgements}

The authors acknowledge thanks to the Ministry of Industry, Tourism, Forests and Environment (MOTIFE), Government of Sudurpaschim province, Nepal, for funding this research. The authors are also thankful to the authorities and user groups of Siddhanath community forest and Manehara community forest for providing necessary information and support throughout the study.

\section{References}

1. Food and Agriculture Organization of the United Nations (FAO), Rome, Italy. FAO Glossary of Terms, 2011. Retrieved from http://www.fao.org/faoterm on February, 2016.

2. K. Brown, D.W. Pearce. The economic value of non-timber benefits of tropical forests: carbon storage. In: J. Weiss (ed) The Economics of Project Appraisal and the Environment. Edward Elgar, London, 1994, Pp 102-123.

3. S. Luyssaert, E.D Schulze, A. Borner, A. Knohl, M.D. Hessen, B.E. Law, P. Ciaiss, J. Grace. Old growth forests as global carbon sinks, Journal of Nature, 2008, 455(5): 213-215. 
4. P.K.R. Nair, B.M. Kumar, V.D. Nair. Agroforestry as a strategy for carbon sequestration, Journal of Plant Nutrition and Soil Science, 2009, 172, 10-23. (DOI: 10.1002/jpln.200800030).

5. R. K. Dixon, S. Brown, R.A. Houghton, A.M. Solomon, M.C. Trexler, J. Wisniewski. Carbon Pools and Flux of Global Forest Ecosystem, Journal of Science, 1994, 263 (5144), 185-190. (DOI: 10.1126/science.263.5144.185).

6. DoF/CFD (Community Forestry Division, Department of Forest), Kathmandu, Nepal, Community Forestry Bulletin, 2018, Vol.18, 1-50.

7. B.K. Pokharel, S. Byrne. Climate change mitigation and adaptation strategies in Nepal's Forest Sector: How can rural communities benefit? Publishers Rights and Resource Initiative, Washington, USA, 2009, PP. 47.

8. DFRS (Department of Forest Research and Survey). State of Nepal's forest. Forest Resources Assessment (FRA), Nepal, MFSC, GoN, 2015, Pp.70.

9. K.B. Thapa Magar, B.B. Shrestha, Carbon stock in community managed Hill Sal (Shorea robusta) forests of Central Nepal, Journal of Sustainable Forestry, 2015, 34(5), 483-501. (DOI: 10.1080/10549811.2015.1031251).

10. P.S. Chauhan, J.D.S. Negi, L.M. Singh, R.K. Monhas. Regeneration status of Sal forests of Doon Valley, Journal of Annals of Forestry, 2008, 16(2), 1781-82.

11. DFRS (Department of Forest Research and Survey), Forest resource assessment Nepal project, Ministry of Forests and Soil Conservation, Babar Mahal, Kathmandu, Nepal. Terai forests of Nepal (2010-2012), 2014a, Pp.70.

12. DFRS (Department of Forest Research and Survey), Forest resource assessment Nepal project, Ministry of Forests and Soil Conservation, Babar Mahal, Kathmandu, Nepal. Churia forests of Nepal (2011-2013), 2014b, Pp.70.

13. N. Hunt, R. Gilkes. Farm Monitoring Hand book, The University of Western Australia: W.A Nedlands, 1992.

14. M.J. Mckenzie, D.J Jacanier, K.L. Brown. Australian Soils and Landscapes Arillustrated Compendium Usiru publishing: Collingwood, Victoria, European Journal of soil science, 2004, 56, 273-280. (Doi.org/10.1111/j.13652389.2004.0694d.x).

15. D.B. Zobel, M.J. Behan, P.K. Jha, U.K.R. Yadav. A Practical Manual for Ecology. Ratna Book Distributors, Bagbazar, Kathmandu, Nepal, 1987, Pp. 149.

16. J. Chave, C. Andalo, S.C. Brown, M.A. Chambers, D. Eamus, T. Yamarkara. Tree allometry and improved estimation of carbon stock and balance in tropical forest, Journal of Oecology, 2005, 145, 87-99.

17. E Zanne, G. Lopez-Gonzales, D.A. Coomes, J. Ilic, S. Jansen, S.L. Lewis, R.B. Miller, SSN.G. Swenson, M.C. Wiemann, and J. Chave, Global Wood Density Database, Dryad Identifier, 2018, retrieved from http://hd/.handle.net/10255/ dryad.235, of $4^{\text {th }}$ Feb. 2009.

18. E. Berlow, C. Antonio, H. Swartz. Response of herbs to shrubs removal across natural and experimental variation in soil moisture, Journal of Ecological Application, 2003, 13(5), 1375-1387. (DOI:10.1890/02-5099).

19. DoF, Community Forestry Division Department of Forest, Community forestry inventory guideline (2061 BS), 2004, Pp 50 .

20. H. Karki, K. Bargali, S.S. Bargali, Y.S. Rawat. Plant Diversity, Regeneration Status and Standing Biomass under Varied Degree of Disturbances in Temperate Mixed Oak- Conifer Forest, Kumaun Himalaya, International Journal of Ecology and Environmental science, 2017, 43(4), 331-345.

21. K.P. Sharma, S.P. Bhatta, G.B. Khatri, A. Pajiyar, D.K. Joshi. Estimation of Carbon Stock in the Chir Pine (Pinus roxburghii sarg.) Plantation Forest of Kathmandu Valley, Central Nepal, Journal of Forest and Environmental science, 2020, 36(1), 37-46. 
22. I.P. Sapkota, M. Tigabu, P.C. Oden. Spatial distribution, advanced regeneration and stand structure of Nepalese Sal (Shorea robusta) forests subject to disturbances to different intensities. Journal of Forest Ecology and Management, 2009, 257, 1966-1975. http://dx.doi.org/10.1016/j.foreco.2009.02.008

23. R.A. Mandal, P.K. Jha, I.C. Dutta, U. Thapa, S.B. Karmacharya. Carbon sequestration in tropical and subtropical plant species in collaborative and community forest of Nepal. Journal of Advances in Ecology, 2016, 1, 1-7.

24. Y.K, Karna. Mapping above ground carbon using world view satellite image and lidar data in relationship with tree diversity and forests, M.S. thesis, University of Twente, Enschede, The Netherlands, 2012.

25. J.S. Singh, S.P. Singh. Forests of Himalaya: Structure, Functioning and Impact of Man. Gyanodaya Prakashan, Nainital, India, 1992, Pp.284.

26. L. Deng, Z. Shangguan. Afforestation driver's soil carbon and nitrogen changes in China. Journal of Land Degradation and Development, 2016, 28 (1), 151-165.

27. M.G. Barbour, J.H. Burk, W.D. Pitts. Terrestrial plant ecology. Publisher Melno Park, the Benjamin Cuming, 1999, Pp. 634. 